\title{
Article \\ Hydrogen as a Maritime Fuel-Can Experiences with LNG Be Transferred to Hydrogen Systems?
}

\author{
Ann Rigmor Nerheim *, Vilmar Æsøy and Finn Tore Holmeset
}

check for updates

Citation: Nerheim, A.R.; Æsøy, V.; Holmeset, F.T. Hydrogen as a Maritime Fuel-Can Experiences with LNG Be Transferred to Hydrogen Systems? J. Mar. Sci. Eng. 2021, 9, 743. https://doi.org/10.3390/jmse9070743

Academic Editors: Eugen Rusu and Tie Li

Received: 9 June 2021

Accepted: 1 July 2021

Published: 5 July 2021

Publisher's Note: MDPI stays neutral with regard to jurisdictional claims in published maps and institutional affiliations.

Copyright: (c) 2021 by the authors. Licensee MDPI, Basel, Switzerland. This article is an open access article distributed under the terms and conditions of the Creative Commons Attribution (CC BY) license (https:/ / creativecommons.org/licenses/by/ $4.0 /)$.
Department of Ocean Operations and Civil Engineering, Norwegian University of Science and Technology (NTNU), 6025 Ålesund, Norway; vilmar.aesoy@ntnu.no (V.Æ.); fiho@ntnu.no (F.T.H.)

* Correspondence: ann.r.nerheim@ntnu.no

\begin{abstract}
As the use of fossil fuels becomes more and more restricted there is a need for alternative fuels also at sea. For short sea distance travel purposes, batteries may be a solution. However, for longer distances, when there is no possibility of recharging at sea, batteries do not have sufficient capacity yet. Several projects have demonstrated the use of compressed hydrogen $\left(\mathrm{CH}_{2}\right)$ as a fuel for road transport. The experience with hydrogen as a maritime fuel is very limited. In this paper, the similarities and differences between liquefied hydrogen $\left(\mathrm{LH}_{2}\right)$ and liquefied natural gas (LNG) as a maritime fuel will be discussed based on literature data of their properties and our system knowledge. The advantages and disadvantages of the two fuels will be examined with respect to use as a maritime fuel. Our objective is to discuss if and how hydrogen could replace fossil fuels on long distance sea voyages. Due to the low temperature of $\mathrm{LH}_{2}$ and wide flammability range in air these systems have more challenges related to storage and processing onboard than LNG. These factors result in higher investment costs. All this may also imply challenges for the $\mathrm{LH}_{2}$ supply chain.
\end{abstract}

Keywords: hydrogen; safety; cryogenic; LNG; maritime; fuel

\section{Introduction}

At present, there are 198 liquefied natural gas (LNG) fueled ships in operation in the world, and further 277 in order [1]. Today, LNG is the most environmentally friendly fossil fuel on the market for maritime purposes [1]. LNG fuels produce no $\mathrm{SO}_{\mathrm{x}}$ emissions, low particle emissions and NOx emissions that are lower than those of conventional fossil fuels [1]. As compared to conventional fuel oils, combustion of LNG reduces the emissions of $\mathrm{SO}_{\mathrm{x}}$ and particles by nearly $100 \%$, and $\mathrm{NO}_{\mathrm{x}}$ by $85 \%$ to $90 \%$ [2]. If hydrogen becomes the preferred maritime fuel in the future, the emissions from the maritime industry can be further reduced or eliminated [1].

So far, only a few maritime vessels have applied hydrogen as a fuel. The first vessel to be operated on hydrogen was Hydra in 2000 [3], followed by Zemships in 2008 [4]. Both these vessels were fueled by compressed hydrogen $\left(\mathrm{CH}_{2}\right)$. Another well-known demonstration project with $\mathrm{CH}_{2}$ is the ship Energy Observer, which has been in operation since 2017 [5]. In 2021/2022, a ferry in Western Norway is planned that uses liquefied hydrogen $\left(\mathrm{LH}_{2}\right)$ in combination with fuel cells and batteries [6,7]. If this project proceeds as planned, it will probably be the first maritime application of $\mathrm{LH}_{2}$ as fuel.

$\mathrm{LH}_{2}$ has been used as rocket fuel in the space industry for decades [8]. However, at present, there are no maritime vessels fueled by $\mathrm{LH}_{2}$ in operation. Hence, there is no practical experience available regarding $\mathrm{LH}_{2}$ systems onboard ships. Therefore, in this paper we will discuss the challenges and applicability of $\mathrm{LH}_{2}$ as a future maritime fuel, based on experiences from LNG systems.

\section{Materials and Methods}

This work is based on available data in literature on various properties of hydrogen, LNG and methane. We have experienced that finding reliable data on the properties of 
hydrogen and LNG is often a difficult task. The paper therefore contributes to making such data and references easier accessible. The objective has been to present an overview of data and use these as a basis for discussing the advantages and disadvantages of $\mathrm{LH}_{2}$ and LNG maritime fuel systems. Our analyses are based on these literature data and our own experiences with design and operation of LNG systems. The work is therefore a qualitative discussion based on data from literature.

\section{Physical Properties of LNG and Hydrogen}

An illustration of a phase diagram of a typical natural gas (NG) is shown in Figure 1, based on data from [9]. As illustrated in the figure, natural gas can be in the gas, liquid or two-phase state, depending on the temperature and pressure conditions. LNG is natural gas that has been cooled down until it liquefies at atmospheric pressure [10]. The origin of natural gas is reservoir fluids. Since the composition of reservoir fluids varies from field to field, the composition of the resulting processed natural gas and LNG also varies [10]. LNG therefore has methane contents varying from 87 to $99 \mathrm{~mol} \%$ around the world [10]. Some of the properties of common LNG qualities and for hydrogen are summarized in Table 1. In the table, flammability data are given for methane $\left(\mathrm{CH}_{4}\right)$, which is the major constituent of LNG.

Table 1. Overview of selected properties of liquefied natural gas (LNG), natural gas (NG), liquefied hydrogen $\left(\mathrm{LH}_{2}\right)$ and compressed hydrogen $\left(\mathrm{CH}_{2}\right)$ with references. Data for methane $\left(\mathrm{CH}_{4}\right)$ has been added where reliable LNG/NG data could not be found.

\begin{tabular}{|c|c|c|c|c|c|}
\hline Property & Dimension & LNG/NG & $\mathrm{LH}_{2} / \mathrm{H}_{2}$ & $\begin{array}{c}\text { Ref. } \\
\text { LNG/NG }\end{array}$ & $\begin{array}{c}\text { Ref. } \\
\mathrm{LH}_{2} / \mathrm{H}_{2}\end{array}$ \\
\hline Mol. weight & $\mathrm{g} / \mathrm{mol}$ & $16.5-18.9$ & 2.0 & [11] & [12] \\
\hline Density & $\mathrm{kg} / \mathrm{m}^{3}$ & 450 (LNG) & 71 & {$[13-15]$} & {$[16]$} \\
\hline Vapor density at standard cond. ( 1 atm., $\left.15^{\circ} \mathrm{C}\right)$ & $\mathrm{kg} / \mathrm{Sm}^{3}$ & $0.7-0.9$ & $(0.08)^{1}$ & [17] & [16] \\
\hline Vapor density at normal cond. $\left(1 \mathrm{~atm} ., 0^{\circ} \mathrm{C}\right)$ & $\mathrm{kg} / \mathrm{Nm}^{3}$ & $(0.7-0.9)^{2}$ & 0.08 & {$[17]$} & {$[16]$} \\
\hline Vapor density at 200 bar & $\mathrm{kg} / \mathrm{m}^{3}$ & 182 & $\mathrm{~N} / \mathrm{A}$ & [18] & \\
\hline Vapor density at 250 bar & $\mathrm{kg} / \mathrm{m}^{3}$ & 215 & $\mathrm{~N} / \mathrm{A}$ & [17] & \\
\hline Vapor density at 350 bar & $\mathrm{kg} / \mathrm{m}^{3}$ & $\mathrm{~N} / \mathrm{A}$ & 23 & & [19] \\
\hline Vapor density at 700 bar & $\mathrm{kg} / \mathrm{m}^{3}$ & $\mathrm{~N} / \mathrm{A}$ & 38 & & [19] \\
\hline Boiling temperature LNG, 1 atm. & ${ }^{\circ} \mathrm{C}$ & $-163 /-161$ & -253 & {$[2] /[13]$} & {$[12]$} \\
\hline Liquid phase temperature at $1-10$ bar & ${ }^{\circ} \mathrm{C}$ & -163 to -130 & -253 to -240 & [9] & {$[20]$} \\
\hline$\Delta \mathrm{T}$ in processing equipment (Amb. temp. $\left.17^{\circ} \mathrm{C}\right)$ & ${ }^{\circ} \mathrm{C}$ & 180 & 270 & [9] & {$[20]$} \\
\hline Energy content of liquefied gas 3 & $\mathrm{GJ} / \mathrm{m}^{3}$ & $(23-24)$ & $(9-10)$ & {$[13,21]$} & {$[16,22]$} \\
\hline Higher heating value & $\mathrm{MJ} / \mathrm{kg}$ & 54 & 142 & {$[13,21]$} & [22] \\
\hline Lower heating value & $\mathrm{MJ} / \mathrm{kg}$ & 50 & 120 & [13] & {$[22]$} \\
\hline Higher heating value of gas & $\mathrm{MJ} / \mathrm{Nm}^{3}$ & 43 & 13 & [23] & {$[16,22]$} \\
\hline Lower heating value of gas & $\mathrm{MJ} / \mathrm{Nm}^{3}$ & 39 & 11 & [23] & {$[16,22]$} \\
\hline Heat capacity at constant pressure & $\mathrm{kJ} / \mathrm{kgK}$ & 2.09 & 14.3 & [23] & {$[24]$} \\
\hline Heat capacity at constant volume & $\mathrm{kJ} / \mathrm{kgK}$ & 1.61 & 10.2 & [23] & {$[25]$} \\
\hline Heat of vaporization & $\mathrm{kJ} / \mathrm{kg}$ & $\begin{array}{l}502-508 / 500 \\
\left(\mathrm{LNG} / \mathrm{CH}_{4}\right)\end{array}$ & 451 & {$[12,26]$} & [27] \\
\hline Lower flammability limit in air (LFL) & $\%$ & $5\left(\mathrm{CH}_{4}\right)$ & 4 & [14] & [28] \\
\hline Upper flammability limit in air (UFL) & $\%$ & $15\left(\mathrm{CH}_{4}\right)$ & 75 & [14] & {$[28]$} \\
\hline Minimum ignition energy & $\mathrm{mJ}$ & $0.28\left(\mathrm{CH}_{4}\right)$ & 0.02 & [29] & [29] \\
\hline Auto-ignition temperature & ${ }^{\circ} \mathrm{C}$ & $599\left(\mathrm{CH}_{4}\right)$ & 560 & [14] & [28] \\
\hline Maximum laminar flame speed in air & $\mathrm{m} / \mathrm{s}$ & 0.374 & 2.933 & [30] & [30] \\
\hline
\end{tabular}

${ }^{1}$ Calculated based on value for $\mathrm{kg} / \mathrm{Nm}^{3}$ [16]. ${ }^{2}$ Calculated based on value for $\mathrm{kg} / \mathrm{Sm}^{3}$ [17]. ${ }^{3}$ Calculated based on referenced data on density, upper and lower gravimetric heating values $[13,16,21,22]$. 


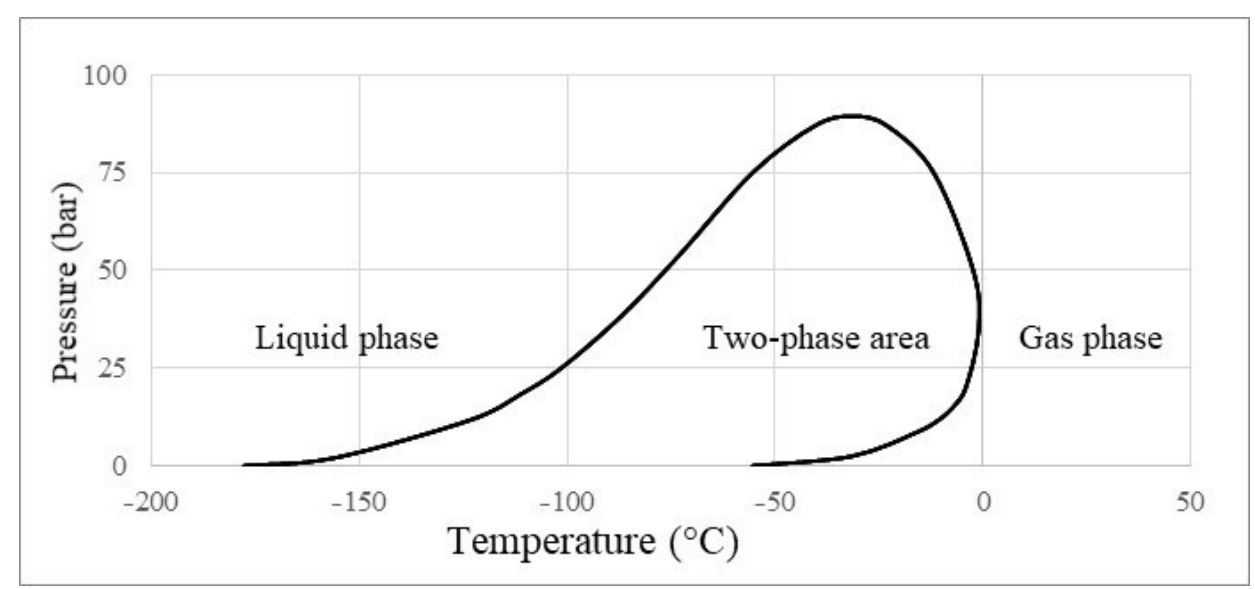

Figure 1. Illustration of a phase diagram of a typical natural gas. The diagram shows the pressure (bar) as a function of temperature $\left({ }^{\circ} \mathrm{C}\right)$ of a typical natural gas. To the left in the diagram the gas is liquefied (LNG), in the two-phase area gas and liquid coexist, and to the right in the diagram only gas phase exists. Data are based on [9].

\section{Energy Density and Fuel Storage Conditions}

On a ship the space available for fuel storage may be limited. The volumetric energy density of the stored fuel is therefore an important parameter. Based on the data in Table 1, LNG has a volumetric energy density that is approximately 2.5 times greater than for $\mathrm{LH}_{2}$. With $\mathrm{CH}_{2}$ the difference in energy density is even higher. This makes $\mathrm{CH}_{2}$ less suitable for long range vessels than $\mathrm{LH}_{2}$. This paper will therefore focus on $\mathrm{LH}_{2}$ as an alternative to LNG for this ship segment.

Both LNG and $\mathrm{LH}_{2}$ are cryogenic substances and are stored at very low temperatures and low pressure, i.e., below 10 bar. The liquid/gas properties of LNG and $\mathrm{LH}_{2}$ are illustrated in Figure 2 over a limited pressure range of 1-10 bar. LNG data are based on [9] and $\mathrm{LH}_{2}$ data are based on [20]. The diagram shows the area of liquid hydrogen between $-253^{\circ} \mathrm{C}$ and the black solid line, and the liquefied natural gas (LNG) region to the left of the curved dotted line. Hydrogen in liquid phase exists only in the temperature interval between $-253^{\circ} \mathrm{C}$ and $-240{ }^{\circ} \mathrm{C}[31]$.

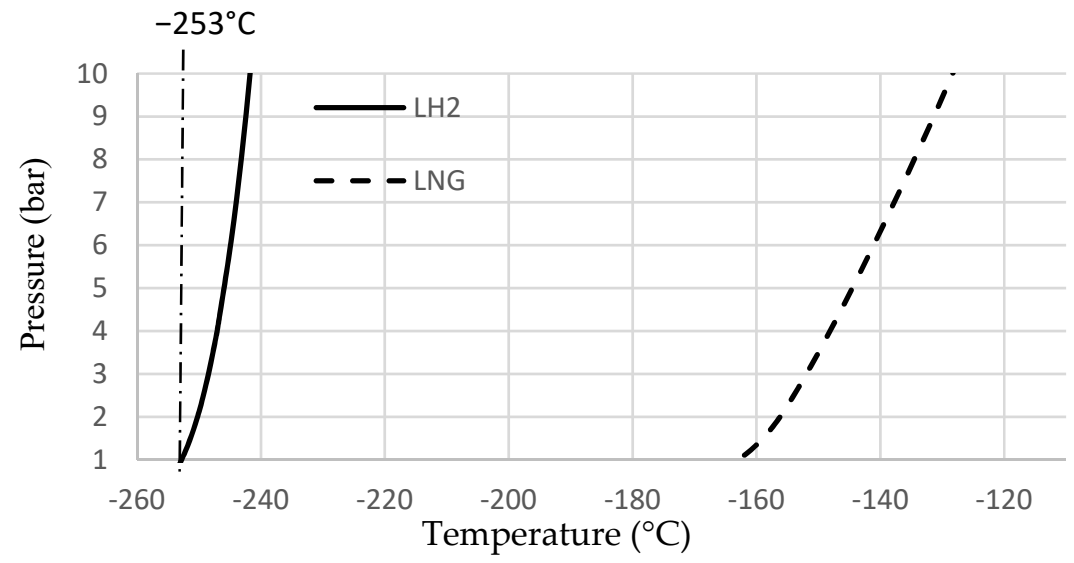

Figure 2. The figure shows the phase diagrams of liquefied hydrogen $\left(\mathrm{LH}_{2}\right)$ and liquefied natural gas (LNG) in the pressure range 1-10 bar as a function of temperature $\left({ }^{\circ} \mathrm{C}\right)$. LNG data are based on [9] and $\mathrm{LH}_{2}$ data are based on [20].

\section{Existing Maritime Gas Fuel Systems Design}

Maritime gas fuel systems may be LNG gas-only, or a combination of several fuel systems, e.g., dual fuel systems [32]. This paper will focus on gas-only systems. A typical maritime LNG gas-only fuel system consists of the main components shown in Figure 3 [33]. 
LNG for fueling the engine is supplied from the liquid phase of the LNG storage tank, evaporated in the main evaporator, and finally the evaporated gas is heated in the superheater to a temperature range in accordance with the specifications of the gas engine. For low pressure systems the minimum fuel gas pressure is typically in the range 3.5-5.3 barg [34], or ca. $4.5-6.3$ bara.

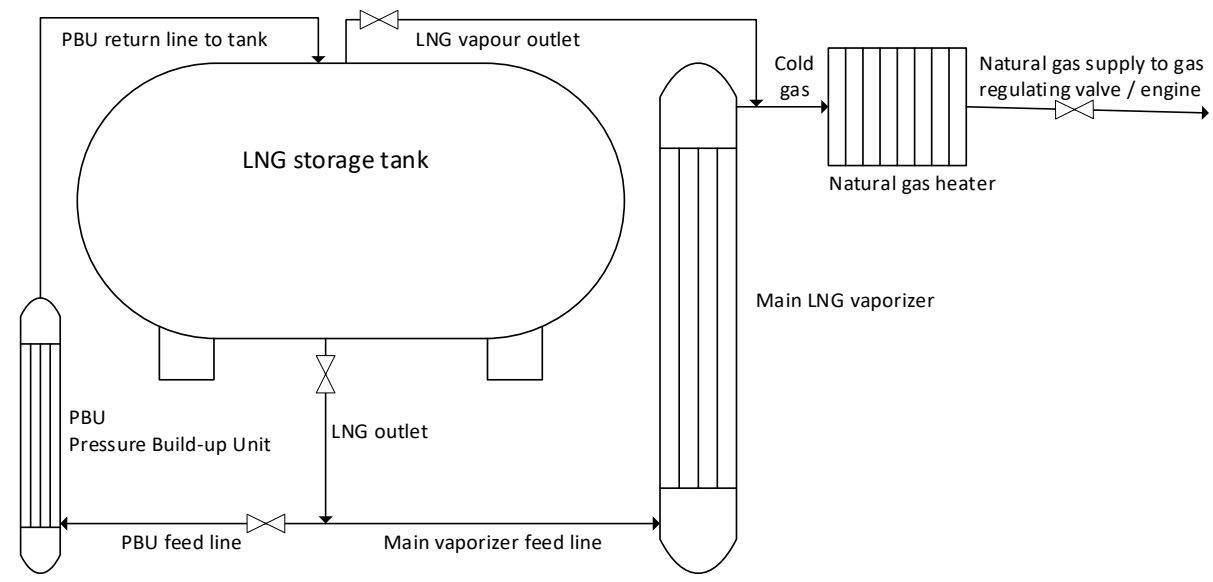

Figure 3. The figure shows a typical liquefied natural gas (LNG) fuel system with a low pressure ( $<10$ bar) LNG storage tank, main vaporizer, gas heater and pressure build-up unit (PBU). An example of a system including an LNG pump is given in [35].

In order to supply the engine with gas at sufficient pressure the LNG storage tank is kept above the required minimum operating pressure of the gas engine. This pressurization of the LNG storage tank is obtained by withdrawing a small amount of LNG from the bottom of the tank, vaporizing/heating it through a separate pressure build-up unit (PBU) and returning the evaporated LNG to the top of the tank as natural gas in vapor state. Hence, the gas phase is at a higher temperature than the liquid phase in the tank. The gas phase is superheated. Since the driving force in this system is gravity only, this type of LNG fuel system is often called a gravity fed system.

During the bunkering process the LNG tank onboard the vessel is loaded with LNG from an LNG production and/or storage facility at $-163{ }^{\circ} \mathrm{C}$ and atmospheric pressure [2]. During this transfer process the LNG may absorb heat from the surroundings through pipe walls and valves. Hence, the temperature of the LNG in the fuel tank will be slightly higher than $-163^{\circ} \mathrm{C}$, depending on the insulation and bunkering process. If the temperature of the LNG in the tank onboard the ship is below ca. $-145^{\circ} \mathrm{C}$ the corresponding vapor pressure is below 4.5 bara, which is a typical minimum pressure required for the engine $[9,34]$.

If sloshing occurs in the tank at these conditions, the "artificial" over-pressure obtained by using the PBU may be partly or totally lost due to condensation. The cold liquid LNG will be sloshing and spraying into the gas phase, thereby cooling the gas down to the temperature of the LNG. As the gas is cooled down it will start to condensate, and the resulting pressure will drop down to the vapor pressure of the LNG at the given LNG temperature $[33,36]$. If this pressure is below the minimum required supply pressure required for the engine, the gas engine may shut down.

As compared to static conditions, sloshing in the tank will in general increase the heat and mass transfer between the liquid and vapor phases. The result is an increased energy absorption in the liquid phase. This leads to a higher LNG temperature and a higher vapor pressure, i.e., a higher boil-off rate [37]. However, this increased boil-off is still a slow process and is therefore not sufficient to maintain the operating pressure in the tank at all conditions. Hence, immediately after bunkering, the consequences of sloshing may be a pressure drop below the minimum required supply pressure to the engine. In the long term, as the LNG absorbs heat, the consequences of sloshing may cause a vapor pressure that is too high as compared to the maximum allowable pressure in the tank. 
In order to guarantee safe supply of gas to the engine at all weather conditions, LNG fuel systems may include an LNG pump [35]. Other means to reduce the impact of sloshing are installation of bulkheads inside the storage tank. Such bulkheads are characterized both by their localization in the tank and the design of the bulkhead surface $[36,38]$. With unsuccessful design of the tank and bulkheads the sloshing impact may be worsened, as described by Grotle [36]. Injection of nitrogen $\left(\mathrm{N}_{2}\right)$ to the gas phase could stabilize the pressure in an LNG tank [39] but would not work in an $\mathrm{LH}_{2}$ tank since liquid hydrogen is colder than $\mathrm{N}_{2}$. An example of a dual fuel system is being developed for a hydrogen tug project [40].

Due to safety measures, and the fuel storage and processing plant itself, LNG systems have been costlier to install than traditional fuel systems [41,42]. They also require more space and are more complicated to operate than the traditional fuel systems. Partly because of the new regulations regarding emission limits, ship owners still choose to install LNG fuel systems. To the authors' knowledge, there have not been any serious accidents related to maritime LNG fuel systems.

\section{Energy Conversion from $\mathrm{LH}_{2}$ and LNG}

Both natural gas and hydrogen may be combusted in a direct combustion engine or by using a fuel cell [29,40-42]. An LNG fuel cell was installed in the Eidesvik vessel "Viking Lady" in 2009 [43]. During a 15-year test and development program this project contributed to the qualification of fuel cell technology on vessels. However, at present internal combustion engines are the most common method for energy conversion from natural gas, and fuel cells are the most common in hydrogen systems. There are several types of fuel cells available today [44]. The main difference between them is the fuel composition, type of electrolyte used, and the ion transporting the charge inside the cell. Some of the various types of fuel cells are listed in Table 2, together with information about operating pressures and energy efficiencies.

Table 2. Overview of fuel cell technologies with preferred fuels and operating conditions. Data from from references as specified in the table.

\begin{tabular}{|c|c|c|c|c|c|}
\hline Abbrev. & Fuel Cell Technology & Fuel & $\begin{array}{l}\text { Operating } \\
\text { Temp. }\left({ }^{\circ} \mathrm{C}\right)\end{array}$ & $\begin{array}{c}\text { Operating Pressure } \\
\text { Range of } \mathrm{H}_{2}\end{array}$ & $\begin{array}{c}\text { Efficiency }^{1} \\
(\%)\end{array}$ \\
\hline PEMFC & Proton Exchange Membrane Fuel Cell & $\mathrm{H}_{2}(\mathrm{~g})[44]$ & $50-70[45]$ & 1-4 atm. $[45,46]$ & $40-60[47]$ \\
\hline DMFC & Direct Methanol Fuel Cell & Methanol [44] & $0-80[44]$ & $1 \mathrm{~atm} .[48]$ & $35-40[47]$ \\
\hline SOFC & Solid Oxide Fuel Cell & $\begin{array}{c}\text { Pure } \mathrm{H}_{2} \text { or } \\
\text { hydrogen-rich fluid [44] }\end{array}$ & $600-900[44]$ & $1-8$ bar [49] & $45-55$ [47] \\
\hline $\mathrm{AFC}$ & Alkaline Fuel Cell & $\mathrm{H}_{2}(\mathrm{~g})[44]$ & $40-150[50]$ & $1-4$ atm. [50] & $45-60[47]$ \\
\hline PAFC & Phosphoric Acid Fuel Cell & $\mathrm{H}_{2}(\mathrm{~g})[44]$ & $160-220[51]$ & 0-4 atm. [51] & $35-45[47]$ \\
\hline PBI & Polybenzimidazole Fuel Cell & $\mathrm{H}_{2}(\mathrm{~g})[44]$ & $120-180[52]$ & $1-3 \mathrm{~atm} .[52]$ & - \\
\hline MCFC & Molten carbonate fuel cell & $\begin{array}{c}\text { Pure } \mathrm{H}_{2} \text { or } \\
\text { hydrogen-rich fluid [44] }\end{array}$ & $650[53]$ & $1-2$ bar $[53]$ & $45-60[47]$ \\
\hline
\end{tabular}

${ }^{1}$ According to [47] these values are approximate numbers from literature and must be treated with caution. The data is only used for comparison of the performance of the different systems.

Research literature on efficiency and operating pressure of fuel cells is limited. However, the available literature indicates that the efficiency of a given fuel cell increases with pressure [45-52]. For both LNG and hydrogen fuel cells the average energy efficiency is $50 \%$ [32]. The average energy efficiency of comparable LNG and dual fuel combustion engines varies from $45 \%$ to $50 \%$ depending engine technology [32]. Hydrogen combustion is quite challenging both in internal combustion engines and gas turbines [29]. The magnitude of the flame velocity and low ignition energy causes combustion instabilities and require special combustion chamber and fuel injector design, as well as special safety arrangements $[54,55]$. Example data on the energy efficiency of the hydrogen internal 
combustion engines are limited, but average values have been indicated to be around $42 \%$ [32].

The first combustion engine using hydrogen as a fuel was invented in 1806 by Isaac de Rivaz [56]. Since then, several efforts have been made to develop a safe, efficient, and cost competitive engine, but the technology is not fully developed yet. Combustion engines burn an air/hydrogen mixture, and the products of the combustion process therefore also includes NOx in addition to water and power. The amount of NOx produced is greatly reduced as compared with emissions from a gasoline engine [57].

Other alternatives are to use a dual fuel engine or gas turbine, or to blend hydrogen into natural gas. In hydrogen-enriched natural gas (HENG), the content of hydrogen is typically up to $20 \mathrm{vol} \%$ [58]. Other hydrogen energy conversion systems have been proposed, e.g., including a gas turbine or a steam turbine [52].

\section{Discussion}

This section gives an evaluation of the applicability of $\mathrm{LH}_{2}$ as a maritime fuel, based on the properties of $\mathrm{LH}_{2}$ and LNG. The discussion focuses on the challenges related to $\mathrm{LH}_{2}$ and LNG with fuel system conditions as described previously. Our results are summarized in Table 3.

Hydrogen and natural gas are both non-toxic, colorless, and odorless gases [1,13,59]. Due to the small molecular size of hydrogen it is more difficult to seal connections and valves for leakages in an $\mathrm{LH}_{2}$ system than in an LNG system [60].

Furthermore, the $\mathrm{LH}_{2}$ temperature at atmospheric pressure is $90{ }^{\circ} \mathrm{C}$ lower than LNG [2,12] (ref. Table 1). In an $\mathrm{LH}_{2}$ system, processing equipment will be subject to large temperature variations. The temperature of materials may change from $-253{ }^{\circ} \mathrm{C}$ to ambient temperature, giving a temperature difference $(\Delta \mathrm{T})$ of around $270{ }^{\circ} \mathrm{C}$. In an LNG system, the equivalent $\Delta \mathrm{T}$ is around $180^{\circ} \mathrm{C}$. As a result of the temperature fluctuations, material contraction and expansion may lead to fatigue and leakages. Moreover, hydrogen is highly reactive, which can lead to degradation of the material and consequently leakage [59]. Hydrogen embrittlement can reduce the tensile strength, ductility, fracture toughness and crack behavior of metals [16]. In an $\mathrm{LH}_{2}$ system the risk of leakages is therefore probably greater than in an LNG system. This implies stricter material requirements in $\mathrm{LH}_{2}$ systems as compared to LNG systems.

Compared to methane, hydrogen is flammable over a wide mixing range with air [14,28] (ref. Table 1). Methane has a flammability range in air of 5 to $15 \%$ by volume, while for hydrogen the flammability range is from 4 to $74 \%$ by volume. Moreover, hydrogen has a lower ignition energy of $0.02 \mathrm{~mJ}$ as compared to $0.28 \mathrm{~mJ}$ for methane [29]. Also, due to the low electroconductivity of hydrogen, flow or agitation of hydrogen gas or liquid may generate electrostatic charges that could result in sparks and thereby causing ignition [60]. Together, these properties make hydrogen more easily ignited than methane.

Laboratory experiments indicate that the flame propagation speed of hydrogen is higher than for methane, and that a hydrogen/air explosion would be more intense than a methane/air explosion, both with respect to explosion pressure and pressure fluctuation [61]. If a hydrogen leakage is ignited, it could burn with a flame speed 10 times faster than for hydrocarbons [58]. Since hydrogen has a much larger flammability range and lower ignition temperature than LNG, this is a major concern related to maritime hydrogen systems. This is especially important when designing the relief valve and flare system.

Both hydrogen (in gas phase) and natural gas are lighter than air, as shown in Table $1[16,17]$. This means that in case of a leakage, the gas will rapidly rise and be diluted, thereby reducing the risk of accidental ignition and burning. Simulation studies show that the dilution distances of subcooled $\mathrm{LH}_{2}$ leaks were significantly longer than for saturated vapor leaks [62]. The reason is that leakages from subcooled $\mathrm{LH}_{2}$ will result in a mixture of gas and liquid phases at the leakage point. I.e. they are denser than a saturated vapor leakage and therefore need a longer distance to be diluted in air. Also, this dense 
two-phase mixture was found to be heavier than air [62]. Similar phenomena have been described in relation to LNG leakages [15,61].

In case of pipeline rupture with large leakages of LNG or $\mathrm{LH}_{2}$, a boiling liquid "pool" may form on the ground. The temperature above the boiling liquid "pool" of LNG or $\mathrm{LH}_{2}$ will be very cold, and the vapor may have a high density/dense phase behavior [62-64]. The gas will therefore probably be diluted much more slowly than from leakages from their respective gas phases $[60,62,65]$. If $\mathrm{LNG}$ or $\mathrm{LH}_{2}$ leaks out at an elevated location onboard the ship, there may therefore be a risk that the vapor moves downwards to the ship instead of upwards in the air. Hence, the vapor cloud may return to ship areas where there are potential sources of ignition. Because of the wider flammability range and lower ignition energy of hydrogen $[14,28,29]$, this constitutes a greater risk in an $\mathrm{LH}_{2}$ system than in an LNG system. Furthermore, this means that a leakage from a pipe with $\mathrm{LH}_{2}$ represents a significantly higher risk than a leakage from a pipe with gaseous hydrogen or natural gas.

As calculated and shown in Table 1 , the energy content is $23-24 \mathrm{GJ} / \mathrm{m}^{3}$ in $\mathrm{LNG}$ and 9-10 GJ/m $\mathrm{m}^{3}$ in $\mathrm{LH}_{2}$, respectively. Hence, the volumetric energy density of $\mathrm{LH}_{2}$ is less than half of that of LNG, which means that the $\mathrm{LH}_{2}$ fluid itself would occupy more space on board the ship than the same energy content stored as LNG.

The space allocation of current fuel cell installations is twice the volume allocated by a traditional combustion engine [66]. If the added volume of the storage tank, as well as the increased weight and costs of the storage tank, insulation and double piping are included, the picture will be even worse for $\mathrm{LH}_{2}$.

If the fuel cell or combustion engine requires a minimum gas supply pressure (ref. Table 2), the type of components in the processing system will be almost identical for LNG and LH2. The reason is that both fuels have the same challenges regarding pressure drop due to sloshing in periods just after bunkering, as previously discussed.

For both fuels, the problem with pressure drop can be solved by either using a dual fuel engine, installing a cryogenic pump, or with careful design of the tank length/diameterratio and installation of special designed bulkheads.

The cryogenic fuel storage tank (type $C$ independent tank) is basically a big thermos with no active cooling of the fluid inside [2]. With LNG or $\mathrm{LH}_{2}$ in a storage tank, the temperature inside the tank will be lower than the temperature of the surroundings outside the tank. Although the tank is insulated, there will be some heat conduction from the surroundings into the tank, resulting in a slow heating of the cold liquid [67].

As the temperature of the fluid in the tank increases, the pressure will increase (ref. Figure 2). If the pressure approaches the maximum design pressure of the tank, the relief valves will open and release gas to the atmosphere. Gas release to the atmosphere is unacceptable from an LNG tank, due to the high GWP of 25 over 100 years for natural gas [18]. Hydrogen is an indirect greenhouse gas with a GWP of 5.8 over 100 years [68]. Although hydrogen has a lower GWP than LNG, it still would have a negative impact on the climate. Also, relief of gas from an $\mathrm{LH}_{2}$ tank has a greater risk of ignition and fire or explosion. Moreover, it is not desirable in view of the large investment costs in producing the hydrogen and cooling it down.

While fuel is consumed from the tank the pressure will normally not build up [2]. Pressure build-up may be a challenge if there are longer periods without consumption from the tank [2]. The pressure build-up rate depends on the tank design, processing system design and movements of the tank (weather conditions) [37]. Therefore, in both $\mathrm{LH}_{2}$ and LNG fuel systems, the storage tank dimensions must be optimized with respect to sailing range, bunkering frequency, and operational profile to avoid reaching the maximum pressure limit of the tank.

The heat conduction from the surroundings and into the fuel storage tank is governed by Fourier's law, as described in [67]. According to this law, the heat flux is proportional to the thermal conductivity, the area of the outer surface of the tank, and the temperature gradient. For storing the same amount of energy as $\mathrm{LNG}, \mathrm{LH}_{2}$ would require approximately twice the volume of the LNG tank, i.e., a larger area of the outer tank surface. Also, the 
temperature gradient from outside to inside of the tank will be $90{ }^{\circ} \mathrm{C}$ higher. With identical insulation, this means that the heat flux into an $\mathrm{LH}_{2}$ tank will be greater than the heat flux into a comparable LNG tank. If the heat capacity and the mass of LH2 and LNG in the tanks are taken into account, the resulting temperature increase rate in the tanks will be in the same range. More thorough simulations are needed to investigate the effect of the heat flux in detail.

However, even if the temperature increase-rate of an $\mathrm{LH}_{2}$ and LNG tank will be in the same range, it is important to note that the resulting effect on the vapor pressure is greater in an $\mathrm{LH}_{2}$ system, as shown in Figure 2. According to Figure 2, the pressure in an LNG tank increases less per ${ }^{\circ} \mathrm{C}$ than in an $\mathrm{LH}_{2}$ tank. In fact, the temperature in the LNG tank could be allowed to increase by more than $30{ }^{\circ} \mathrm{C}$ before the pressure reaches the maximum tank design pressure of 10 bar [9]. In comparison, the $\mathrm{LH}_{2}$ temperature can only be allowed to increase by $13^{\circ} \mathrm{C}$ before reaching the 10 bar pressure limit [20].

Hydrogen exists in liquid phase only in the temperature interval between $-253{ }^{\circ} \mathrm{C}$ and $-240{ }^{\circ} \mathrm{C}$ [31]. Hence, $\mathrm{LH}_{2}$ must be maintained within this temperature range of $\Delta \mathrm{T}=13{ }^{\circ} \mathrm{C}$ throughout the distribution chain. Preventing heating during reloading and storage along the value chain is therefore even more important for $\mathrm{LH}_{2}$ than for LNG. LNG is easier to handle than $\mathrm{LH}_{2}$, since it can be maintained in liquid phase and below a pressure of 10 bar over a temperature range of $30^{\circ} \mathrm{C}$.

The tank operational properties must comply with the requirements of 15 days holding time, as stated by the IGF code [2]. It is therefore important to build $\mathrm{LH}_{2}$ tanks with considerably more efficient insulation than in comparable LNG tanks. An overview of the most common (passive) insulation methods for LNG tanks and the resulting thermal conductivity is given in $[67,69]$. Another solution would be to design a storage tank with an active cooling system [70].

The above described challenges with heat conduction from the surroundings can be limited but not eliminated. For these reasons, the energy supply chains for both LNG and $\mathrm{LH}_{2}$ supply must be customized according to the consumer demand. In this way, it is possible to limit the storage time, thereby reducing the risk of pressure build up and avoiding gas release to the atmosphere. Due to the extremely low temperature of $\mathrm{LH}_{2}$ as compared to LNG, and the smaller temperature interval of liquid phase with pressure below 10 bar, this challenge is greater for $\mathrm{LH}_{2}$ than for LNG systems. This is probably one of the major challenges with $\mathrm{LH}_{2}$ with respect to implementation as a fuel in maritime industry. Infrastructure with proper pre-cooling facilities is crucial, to minimize the heat leak during pipe transfer and reloading. It is also important to reduce the number of re-loadings along the supply chain, and to minimize the transport time (distance) from producer to consumer.

In LNG systems, nitrogen is usually used for purging and cooling, since it is an inert gas that is colder than LNG. Liquid nitrogen $\left(\mathrm{LN}_{2}\right)$ has a boiling temperature of $-196{ }^{\circ} \mathrm{C}$ at atmospheric pressure [1], i.e., below the boiling point of LNG of $-163{ }^{\circ} \mathrm{C}$ as given in Table 1 [2]. $\mathrm{LN}_{2}$ therefore works well for inerting and pre-cooling pipelines before starting the transfer of LNG [67]. $\mathrm{LH}_{2}$ has a boiling point of $-253{ }^{\circ} \mathrm{C}$ at atmospheric pressure and is colder than $\mathrm{LN}_{2}$, so $\mathrm{LN}_{2}$ is not as well suited for cooling a $\mathrm{LH}_{2}$ system as in an LNG system. Hence, $\mathrm{LN}_{2}$ works as a tool for inerting the pipeline before $\mathrm{LH}_{2}$ transfer but is less efficient in pre-cooling it. Instead, helium gas with boiling point at $-296{ }^{\circ} \mathrm{C}$ may be used for inerting and cooling in $\mathrm{LH}_{2}$ systems [70].

Onboard LNG fueled ships, gas sensors must be installed near locations where there are higher risks of leakages, and/or higher consequences of leakages, in accordance with the requirements of the IGF Code [71]. Because of the wider flammability range and the lower ignition energy (ref. Table 1), a leakage of hydrogen will most likely constitute a higher risk and more serious consequences than a leakage of LNG. Double barriers must therefore be a requirement in hydrogen systems, in combination with other safety means, e.g., double piping. In double piping systems, the fuel gas is contained in the inner pipe, while the space between the concentric pipes may be pressurized with an inert gas at a 
higher pressure than the fuel gas in the inner pipe [71]. Other means of reducing the risks are adding sensors and enhancing the ventilation or using inert atmosphere in the tank connection space [71]. Localization of the $\mathrm{LH}_{2}$ tank on open deck could be advantageous with respect to ventilation conditions and reduced risk of entrapment of flammable gas clouds. However, on open deck the risk of damage to the $\mathrm{LH}_{2}$ tank and subsequent leakage would be higher.

Table 3. The table shows a summary of the discussion of the applicability of liquefied hydrogen $\left(\mathrm{LH}_{2}\right)$ as a maritime fuel. In the table, $\mathrm{LH}_{2}$ is compared to liquefied natural gas (LNG) as a maritime fuel. Only properties where $\mathrm{LH}_{2}$ and $\mathrm{LNG}$ show significant differences are listed here. (" 0 ": The challenges are similar for $\mathrm{LH}_{2}$ and LNG systems. " $\div$ ": The given characteristics constitutes a disadvantage for $\mathrm{LH}_{2}$ systems as compared to LNG systems. "+": The given characteristics constitutes an advantage for $\mathrm{LH}_{2}$ systems as compared to LNG systems).

\begin{tabular}{|c|c|c|}
\hline Property & $\begin{array}{l}\mathrm{LH}_{2} \\
\text { vs. } \mathrm{LNG}\end{array}$ & Comment \\
\hline Molecular size & $\div$ & Smaller molecular size than methane. More difficult to avoid leaks [60]. \\
\hline Temperature at $1 \mathrm{~atm}$. & $\div$ & $\begin{array}{l}-253^{\circ} \mathrm{C} \text { for } \mathrm{LH}_{2} \text { vs. }-163{ }^{\circ} \mathrm{C} \text { for } \mathrm{LNG}[2,12] \text {. Requires more efficient insulation. } \\
\text { Higher risk of embrittlement. Requires higher material quality in pipes. }\end{array}$ \\
\hline $\begin{array}{l}\text { Liquid phase temperature interval } \\
\text { at } 1-10 \text { bar pressure }\end{array}$ & $\div$ & $\begin{array}{l}\Delta \mathrm{T}=13^{\circ} \mathrm{C} \text { for } \mathrm{LH}_{2} \text { vs. } \Delta \mathrm{T}=30^{\circ} \mathrm{C} \text { for } \mathrm{LNG}[9,20] . \text { Requires more efficient } \\
\text { control of heat leak during reloading, transport and storage. }\end{array}$ \\
\hline $\begin{array}{l}\Delta \mathrm{T} \text { in processing equipment } \\
\left(\text { Ambient temp. } 17^{\circ} \mathrm{C}\right)\end{array}$ & $\div$ & $\begin{array}{l}\Delta \mathrm{T}=270{ }^{\circ} \mathrm{C} \text { for } \mathrm{LH}_{2} \text { vs. } \Delta \mathrm{T}=180^{\circ} \mathrm{C} \text { for LNG. Higher risk of fatigue and } \\
\text { embrittlement. Requires higher material quality. }\end{array}$ \\
\hline Reactivity & $\div$ & Higher reactivity. Requires higher material quality $[16,59]$ \\
\hline Dense phase behavior of leakages & 0 & $\begin{array}{l}\text { Similar to LNG systems }[61,62] \text {. Risk of gas with negative buoyancy returning } \\
\text { to ship areas and potential ignition sources. }\end{array}$ \\
\hline Energy content of liquid phase & $\div$ & $\begin{array}{l}\text { Lower volumetric energy content (ref. Table 1). Requires bigger fuel storage } \\
\text { tank onboard the ship. }\end{array}$ \\
\hline Heat capacity & + & $\begin{array}{l}\text { Higher heat capacities }[16,23] \text {. Requires more energy to heat } 1 \mathrm{~kg} \text { gas } 1{ }^{\circ} \mathrm{C} \text {. } \\
\text { Advantageous wrt. heating rate during storage. }\end{array}$ \\
\hline Heat of vaporization & $(\div)$ & Slightly lower than for LNG in kJ/kg $[26,27]$. \\
\hline $\begin{array}{l}\text { Heat flux from surroundings and } \\
\text { into the tank }\end{array}$ & $\div$ & Higher heat flux, if the insulation used is similar to what is used in LNG tanks. \\
\hline Flammability range in air & $\div$ & $\begin{array}{l}\text { Wider, i.e., flammable conditions are more easily formed }[14,28] \text {. Higher risk of } \\
\text { fire and/or explosion. }\end{array}$ \\
\hline Ignition energy & $\div$ & Low, i.e., more easily ignited than LNG [29]. \\
\hline Auto-ignition temperature & $(\div)$ & Slightly lower than methane $[13,28]$. \\
\hline Maximum laminar flame speed in air & $\div$ & Higher than for natural gas [22]. Greater risk of spreading of fire. \\
\hline Space allocation of fuel cell & $\div$ & Space allocation of fuel cell is twice the volume of combustion engines [66]. \\
\hline Pressure drop due to sloshing in tank & 0 & Similar to LNG systems. \\
\hline Purging and cooling of equipment & 0 & Helium can be used instead of nitrogen [70]. \\
\hline Global Warming Potential (GWP) & + & $\begin{array}{l}5.8 \text { vs. } 25 \text { over } 100 \text { years [68]. Less damaging for the climate in case of leakage } \\
\text { to the atmosphere. }\end{array}$ \\
\hline Training of operating personnel & 0 & Required for both LH2 and LNG systems. \\
\hline Availability as maritime fuel & $\div$ & $\begin{array}{l}\text { Supply chain of } \mathrm{LH}_{2} \text { as maritime fuel is not established. Supply chains for } \\
\text { LNG are well established in some regions [2]. }\end{array}$ \\
\hline
\end{tabular}

A recent concept risk analysis of a high-speed passenger ferry powered by $\mathrm{CH}_{2}$ concluded that the risk related to the compressed hydrogen system is within acceptable risk tolerance level [72]. Similar analyses must be performed on $\mathrm{LH}_{2}$ systems, since these systems have considerably more safety challenges than $\mathrm{CH}_{2}$, as discussed above. Based on such risk analyses, requirements for double piping, ventilation and location of sensors may 
be described. Finally, the total costs of the system will be crucial for the decision of the ship owner to choose $\mathrm{LH}_{2}$ as a fuel. A study of the feasibility and commercial considerations of LNG fueled ships have been published by [73]. The costs must be competitive to the costs of LNG systems, including emission taxes. Other important factors in the decision process is the potential loss of cargo space, uncertainties related to bunkering infrastructure and fuel availability [73].

Finally, one of the most important factors regarding safety is the operating personnel. They need to be trained, so that they know the system, the potential risks, and the mitigation procedures. Operating procedures and safety routines must be developed. The personnel must be aware of the differences between systems for traditional fuels and hydrogen and must wear protective gear according to the actual operation activity.

\section{Conclusions}

In this paper, an evaluation of $\mathrm{LH}_{2}$ and LNG as maritime fuels has been given. Although $\mathrm{LH}_{2}$ is a cryogenic fuel like LNG, transferring from LNG to LH2 as a maritime fuel is not straightforward. Some of the experiences with LNG are transferable to $\mathrm{LH}_{2}$ maritime systems. Basically, the fuel processing systems of LNG and $\mathrm{LH}_{2}$ will contain similar main components. However, LH2 is an even more challenging fuel than LNG when it comes to safety, storage time, supply chain and space onboard the ship. This is due to the low temperature, higher risk of leakages, wider flammability range, lower ignition energy, sensitivity to heat leak and lower volumetric density.

Significantly higher safety restrictions must be applied for $\mathrm{LH}_{2}$ fueled maritime systems than for LNG systems. IMO, IGF and Class societies' rules and regulations need to be adapted accordingly. Mitigation measures must include double piping, inert gas systems and ventilation, detectors, and safety procedures. Optimal placement of the $\mathrm{LH}_{2}$ storage tank onboard the ship must be identified through risk analyses. The analyses must evaluate the risk of leakages and entrapment of flammable gas mixtures versus risk of external damage of the tank. This includes analyses of probable diffusion distances, dilution rates of gas leakages and possible ignition sources. As a result of the regulatory framework [69], present LNG systems onboard ships are designed to be able to handle potential leakages. In an $\mathrm{LH}_{2}$ fueled ship, risk of leakages cannot be accepted. Based on our analyses, the main challenges for implementing LH2 as a maritime fuel are:

- How can $\mathrm{LH}_{2}$ be maintained at low temperature, with a minimum of heat loss and a minimum of pressure increase? What are the implications for tank design, insulation and active cooling methods?

- What are the safety implications regarding tank localization onboard the ship?

- How can the relief valve and flare system be designed and localized to minimize the risk of fire and explosion?

- What are the material, system and design requirements for the piping and processing system?

- What are the total costs per $\mathrm{kWh}$ at propeller, as compared to other renewable or low carbon energy carriers?

- How to develop procedures for personnel handling $\mathrm{LH}_{2}$ in maritime fuel systems? Procedures must be developed for safe handling of $\mathrm{LH}_{2}$ during transport, distribution, transfer, bunkering, storage, and consumption on board the ship.

When it comes to investments on-board the ship, $\mathrm{LH}_{2}$ systems will probably be costlier than today's LNG systems. The number of main components in the fuel system may not be very different, but $\mathrm{LH}_{2}$ will require higher material quality, extensive use of double piping and sensors.

The availability of $\mathrm{LH}_{2}$ is still limited. There are plans for hydrogen production plants and hydrogen distribution networks, but the availability is still too limited for it to be a commercial alternative fuel. According to the European Commission $96 \%$ of hydrogen available today comes from fossil fuels [74]. Renewable hydrogen can be produced from electrolysis of water using wind and solar energy as power sources. However, this will 
require cost reductions in electrolyser technologies, which are not expected to be fully mature until 2030 the earliest. Whichever production method is used, the $\mathrm{CO}_{2}$ emission from transport of the hydrogen from the production plant to the end user must be included in the evaluation.

As compared to $\mathrm{LNG}, \mathrm{LH}_{2}$ has a more limited storage time. It is therefore important to produce $\mathrm{LH}_{2}$ as close as possible to the consumer and to reduce the number of re-loading operations. Hence, $\mathrm{LH}_{2}$ may not be suited for global trade in the same extent as LNG. For maritime application, it would be advantageous to supply $\mathrm{LH}_{2}$ from a local or short-range value chain. This would reduce the intermediate storage time in transportation and the $\mathrm{CO}_{2}$ emission related to transport.

For hydrogen to become a realistic alternative as a maritime fuel, pilot projects must be able to demonstrate that $\mathrm{LH}_{2}$ systems are at least as safe as LNG systems. Furthermore, supply chains for hydrogen produced from renewable energy must be established. Control and logistics of the $\mathrm{LH}_{2}$ supply chain is even more critical than for LNG, due to the narrow temperature interval where hydrogen is in liquid state, and due to the higher risk of leakages. Personnel training courses and procedures for safe operation of maritime fuel systems must be developed of the relevant authorities as soon as possible.

Author Contributions: Conceptualization, A.R.N.; writing-original draft preparation, A.R.N.; writing-review and editing, A.R.N., V.Æ. and F.T.H. All authors have read and agreed to the published version of the manuscript.

Funding: This research received no external funding.

Institutional Review Board Statement: Not applicable.

Informed Consent Statement: Not applicable.

Data Availability Statement: Not applicable.

Conflicts of Interest: The authors declare no conflict of interest.

\section{References}

1. DNV. Alternative Fuels Insight Platform. Available online: https:/ /afi.dnvgl.com/Statistics?repId=1 (accessed on 29 April 2021).

2. IMO-International Maritime Organization. Studies on the Feasibility and Use of LNG as a Fuel for Shipping; Published by the International Maritime Organization, 2016. Available online: https:/ /iwlearn.net/documents/32778 (accessed on 11 October 2020).

3. dieBrennstoffzelle.de. Brennstoffzellen-Boot Hydra; dieBrennstoffzelle: Osterholz-Scharmbeck, Germany, 2021. Available online: http:/ / www.diebrennstoffzelle.de/h2projekte/mobil/hydra.shtml (accessed on 20 February 2021).

4. Prasad, R. The Zemship project-A case study in maritime applications. In Proceedings of the Maritime Hydrogen and Fuel Cells Conference, Bergen, Norway, 3 September 2019.

5. Energy Observer. Available online: 2020.https://www.energy-observer.org/en/ (accessed on 20 February 2021).

6. Stensvold, T. Norled Bygger Verdens første Hydrogen-Ferge; TU Maritim: Oslo, Norway, 2018. Available online: https:/ /www.tu.no/ artikler/norled-bygger-verdens-forste-hydrogen-ferge/452526. (accessed on 20 February 2021).

7. Moore, R. Norled Project to Deploy Hydrogen ferry; Riviera: Enfield, UK, 2019. Available online: https:/ /www.rivieramm.com/ news-content-hub/news-content-hub/norled-project-to-deploy-hydrogen-ferry-54731 (accessed on 26 March 2020).

8. NASA. Space Applications of Hydrogen and Fuel Cells; NASA-National Aeronautics and Space Administration: Dunbar, UK, 2017. Available online: https:/ / www.nasa.gov/content/space-applications-of-hydrogen-and-fuel-cells (accessed on 20 July 2020).

9. Katyal, A. Accurate prediction of phase equilibrium properties-Part 1. In Hydrocarbon Processing; Gulf Publishing Company LLC: Houston, TX, USA, 2019. Available online: https:/ /www.hydrocarbonprocessing.com/magazine/2019/october-2019/processoptimization/accurate-prediction-of-phase-equilibrium-properties-part-1 (accessed on 1 June 2021).

10. GIIGNL-International Group of LNG Importers. GIIGNL Annual Report; International Group of Liquefied Natural Gas Importers (GIIGNL): Neuilly-sur-Seine, France, 2018. Available online: https://giignl.org/sites/default/files/PUBLIC_AREA/ Publications/rapportannuel-2018pdf (accessed on 11 October 2020).

11. Desfa. LNG Quality Specifications; Desfa: Chalandri, Greece, 2020. Available online: https://www.desfa.gr/en/regulatedservices/lng/users-information-lng/quality-specifications (accessed on 10 October 2020).

12. Blackman, A.G. Aylward and Findlay's SI Chemical Data, 7th ed.; Blackman, A.G., Gahan, L.R., Aylward, G., Findlay, T., Eds.; John Wiley \& Sons: Milton, QLD, Australia, 2014; ISBN 9780730302469.

13. IGU-International Gas Union. Natural Gas Conversion Guide; IGU, Office of the Secretary General: Oslo, Norway, 2012. Available online: http:/ /agnatural.pt/documentos/ver/natural-gas-conversion-guide_cb4f0ccd80ccaf88ca5ec336a38600867db5aaf1.pdf (accessed on 10 October 2020). 
14. GIIGNL-The International Group of Liquefied Natural Gas Importers. LNG Information Paper \#1—Basic Properties of LNG; International Group of Liquefied Natural Gas Importers (GIIGNL): Neuilly-sur-Seine, France, 2019. Available online: https:/ /giignl.org/ sites/default/files/PUBLIC_AREA/About_LNG/4_LNG_Basics/giignl2019_infopapers1.pdf (accessed on 11 October 2020).

15. Benito, A. Accurate determination of LNG quality unloaded in receiving terminals-An innovative approach. In Proceedings of the 24th World Gas Conference, Buenos Aires, Argentina, 5-9 October 2009. Available online: http: / / www.iapg.org.ar/WGC09/admin/archivosNew/Special\%20Projects/4.\%20IGU\%20Best\%20Practices/4.\%20IGU\%20Best\% 20Practices\%20FINAL\%20-\%20CD\%20contents / 8.\%20LNG\%20-\%20Accurate\%20determination\%20of\%20LNG\%20quality\% 20unloaded\%20in\%20receiving\%20terminals.pdf (accessed on 11 October 2020).

16. NASA Safety Training Center. Safe Use of Hydrogen and Hydrogen Systems; Revision 2006; NTRS-NASA Technical Reports Server: Washington, DC, USA, 2006. Available online: https://ntrs.nasa.gov/archive/nasa/casi.ntrs.nasa.gov/20070018005.pdf (accessed on 20 July 2020).

17. Unitrove Limited. Compressed Natural Gas (CNG); Unitrove Limited: Leicestershire, UK, 2020. Available online: https://www. unitrove.com/engineering/gas-technology/compressed-natural-gas (accessed on 11 October 2020).

18. Eswara, A.K.; Misra, S.C.; Ramesh, U.S. Introduction to natural gas: A comparative study of its storage, fuel costs and emissions for a harbor tug. In Proceedings of the Annual Meeting of Society of Naval Architects \& Marine Engineers (SNAME), Bellevue, WA, USA, 8 November 2013. Available online: https:/ / www.researchgate.net/publication/262691939_Introduction_to_natural_ gas_A_comparative_study_of_its_storage_fuel_costs_and_emissions_for_a_harbor_tug/link/0a85e53abc9046525e000000/ download (accessed on 11 October 2020).

19. Sheffield, J.W.; Martin, K.B.; Folkson, R. Electricity and hydrogen as energy vectors for transportation vehicles. In Alternative Fuels and Advanced Vehicle Technologies for Improved Environmental Performance-Towards Zero Carbon Transportation; Woodhead Publishing Limited, Series in Energy; Elsevier: Oxford, UK, 2014; No. 57, ISBN 978-0-85709-522-0. [CrossRef]

20. NIST Standard Reference Database Number 69. In NIST Chemistry WebBook; Thermophysical Properties of Fluids and SystemsHydrogen Saturation Properties-Pressure Increments; National Institute of Standards and Technology, Department of Commerce: Washington, DC, USA, 2018. Available online: https:/ / webbook.nist.gov/chemistry/ (accessed on 29 March 2021).

21. IGU; BP. Guidebook to Gas Interchangeability and Gas Quality; BP: Sunbury on Thames, UK; IGU: Oslo, Norway, 2011. Available online: https: / /www.igu.org/app/uploads-wp/2011/08/Guidebook-to-Gas-Interchangeability-and-Gas-Quality-August-20 11-min.pdf (accessed on 11 October 2020).

22. Ogden, J.M. Hydrogen: The Fuel of the Future? Phys. Today 2002, 55, 69-75. [CrossRef]

23. REN-Gasodutos. Gas Properties; Ren, Portugal, 2008. Document Number M-00000-SPC-MI-0002. Available online: http: //www.mercado.ren.pt/PT/Gas/InfoMercado/Documentacao/BibOutros/GasProperties.pdf (accessed on 11 October 2020).

24. Nuclear Power. Hydrogen—Specific Heat, Latent Heat of Fusion, Latent Heat of Vaporization; Nuclear Power (Website), 2019. Available online: https:/ / www.nuclear-power.net/hydrogen-specific-heat-latent-heat-vaporization-fusion/ (accessed on 25 April 2020).

25. NCEES. FE Reference Handbook; NCEES: Clemson, CA, USA, 2013; ISBN 978-1-932613-67-4. Available online: http://www. engineering.uco.edu/ \{\}aabuabed/index_files/fe_handbook.pdf (accessed on 11 October 2020).

26. Włodek, T. Analysis of boil-off rate problem in Liquefied Natural Gas (LNG) receiving terminals. In IOP Conference Series: Earth and Environmental Science; IOP Publishing Ltd.: Bristol, UK, 2019; Volume 214, p. 012105.

27. McAllister, S.; Chen, J.Y.; Fernandez-Pello, A.C. Thermodynamics of combustion. In Fundamentals of Combustion Processes. Mechanical Engineering Series; Springer: New York, NY, USA, 2011.

28. Schmidtchen, U. Fuels-Safety, Hydrogen: Overview. In Encyclopedia of Electrochemical Power Sources; Garche, J., Dyer, C., Moseley, P., Ogumi, Z., Rand, D., Scrosati, B., Eds.; Elsevier: Amsterdam, The Netherlands, 2009; pp. 519-527, ISBN 9780444527455.

29. Verhelst, S.; Demuynck, J.; Sierens, R.; Scarcelli, R.; Matthias, N.S.; Wallner, T. Chapter 16-Update on the Progress of Hydrogen-Fueled Internal Combustion Engines. In Renewable Hydrogen Technologies; Elsevier: Oxford, UK, 2013; pp. 381-400, ISBN 9780444563521. [CrossRef]

30. Dong, C.; Zhou, Q.; Zhang, X.; Zhao, Q.; Xu, T.; Hui, S. Experimental study on the laminar flame speed of hydrogen/natural gas/air mixtures. Front. Chem. Eng. China 2010, 4, 417-422. [CrossRef]

31. Züttel, A. Hydrogen storage methods. Sci. Nat. 2004, 91, 157-172. [CrossRef]

32. DNV GL. Comparison of Alternative Marine Fuels; Report No. 2019-0567, Rev3, 05 July 2019; Sea \LNG Ltd.: Glasgow, Scotland, UK, 2019. Available online: https:/ / sea-lng.org/reports/comparison-of-alternative-marine-fuels / (accessed on 31 May 2021).

33. Nerheim, A.R.; Oppedal, S.; Mortensen, A. LNG fuel systems for ships-Experiences, challenges and solutions. In Proceedings of the 6th Gas Fuelled Ships Conference, Hamburg, Germany, 10-12 November 2015.

34. Rolls-Royce. Medium-Speed Generation Sets Portfolio; Booklet Edition 1-2020; Rolls-Royce Group: Bergen, Norway, 2020. Available online: https://bergen.rolls-royce.com/Portals/_default/assets/1/677/252_BookletEdition1-2020.pdf (accessed on 25 May 2021).

35. Oppedal, S.; Mortensen, A.; Nerheim, A.R.; Chirkowski, J. Method and System for Conditioning of LNG. Norwegian Patent NO338906B1, 23 December 2014.

36. Grotle, E.L. Thermodynamic Response Enhanced by Sloshing in Marine LNG Fuel Tanks_Experimental Work and Numerical Modelling. Ph.D. Thesis, NTNU-Norwegian University of Science and Technology, Faculty of Engineering, Department of Ocean Operations and Civil Engineering, Trondheim, Norway, April 2018. 
37. Wu, S.; Ju, Y. Numerical study of the boil-off gas (BOG) generation characteristics in a type C independent liquefied natural gas (LNG) tank under sloshing excitation. Energy 2021, 223, 120001. [CrossRef]

38. Oppedal, S.; Mortensen, A.; Nerheim, A.R. Tank with Sloshing Bulkheads. Norwegian Patent NO338150B1, 25 November 2014.

39. Nerheim, A.R.; Oppedal, S.; Mortensen, A. System and Method for Conditioning Pressure in an LNG Tank. Norwegian Patent NO339027B1, 15 July 2015.

40. Kalyanaraman, A. Tug Project Leads the Way for 1 MW+ Hydrogen-Burning Engines; Riviera Maritime Media Ltd.: Enfield, UK, 1 November 2019. Available online: https: / / www.rivieramm.com/news-content-hub/news-content-hub/tug-project-leads-theway-for-hydrogen-burning-mw-engines-56680 (accessed on 3 January 2020).

41. Æsøy, V.; Einang, P.M.; Stenersen, D.; Hennie, E.; Valberg, I. LNG-Fuelled Engines and Fuel Systems for Medium-Speed Engines in Maritime Applications; SAE Technical Paper; SAE International: Warrendale, PA, USA, 2011. [CrossRef]

42. Æsøy, V.; Stenersen, D. Low emission LNG fuelled ships for environmental friendly operations in arctic areas. In Proceedings of the ASME 2013 32nd International Conference on Ocean, Offshore and Arctic Engineering, OMAE2013, Polar and Arctic Sciences and Technology; Offshore Geotechnics; Petroleum Technology Symposium, Nantes, France, 9-14 June 2013; Volume 6, V006T07A028. [CrossRef]

43. Wärtsila. Leading the Way towards the World's First Zero Emissions Supply Vessel; Wärtsila: Helsinki, Finland, 2020. Available online: https:/ / www.wartsila.com/media/news/04-02-2020-leading-the-way-towards-the-world-s-first-zero-emissionssupply-vessel (accessed on 29 April 2021).

44. Burheim, O.S. Hydrogen for Energy Storage; Elsevier Inc.: Oxford, UK, 2017; ISBN 9780128141007.

45. Wang, L.; Husar, A.; Zhou, T.; Liu, H. A parametric study of PEM fuel cell performances. Int. J. Hydrogen Energy 2003, 28, 1263-1272. [CrossRef]

46. Yan, Q.; Toghianib, H.; Causey, H. Steady state and dynamic performance of proton exchange membrane fuelcells (PEMFCs) under various operating conditions and load changes. J. Power Sources 2006, 161, 492-502. [CrossRef]

47. Dell, R.M.; Moseley, P.T.; Rand, D.A.J. Chapter 8-Hydrogen, Fuel Cells and Fuel Cell Vehicles. In Towards Sustainable Road Transport; Dell, R.M., Moseley, P.T., Rand, D.A.J., Eds.; Academic Press: Oxford, UK, 2014; pp. 260-295, ISBN 9780124046160.

48. Tafaoli-Masoule, M.; Bahrami, A.; Mohammadrezaei, D. Optimum Conditions for Maximum Power of a Direct Methanol Fuel Cell. In International Scholarly Research Notices; Hindawi Publishing Corporation, Hindawi Limited: London, UK, 2013; Volume 2013, Article ID 872873. Available online: https:/ / www.hindawi.com/journals/isrn/2013/872873/ (accessed on 19 July 2020).

49. Henke, M.; Willich, C.; Westner, C.; Leucht, F.; Leibinger, R.; Kallo, J.; Friedrich, K.A. Effect of pressure variation on power density and efficiency of solid oxide fuel cells. Electrochim. Acta 2012, 66, 158-163. [CrossRef]

50. McLean, G. An assessment of alkaline fuel cell technology. Int. J. Hydrogen Energy 2002, 27, 507-526. [CrossRef]

51. Song, R.-H.; Shin, D.R. Influence of CO concentration and reactant gas pressure on cell performance in PAFC. Int. J. Hydrogen Energy 2001, 26, 1259-1262. [CrossRef]

52. Ubong, E.U.; Shi, Z.; Wang, X. Three-Dimensional Modeling and Experimental Study of a High Temperature PBI-Based PEM Fuel Cell. J. Electrochem. Soc. 2009, 156, B1276-B1282. [CrossRef]

53. Ahn, J.; Park, S.H.; Lee, S.; Noh, Y.; Chang, D. Molten carbonate fuel cell (MCFC)-based hybrid propulsion systems for a liquefied hydrogen tanker. Int. J. Hydrogen Energy 2018, 43, 7525-7537. [CrossRef]

54. Kim, Y.J.; Yoon, Y.; Lee, M.C. On the observation of high-order, multi-mode, thermo-acoustic combustion instability in a model gas turbine combustor firing hydrogen containing syngases. Int. J. Hydrogen Energy 2019, 44, 11111-11120. [CrossRef]

55. Verma, S.; Kaushik, S.C.; Das, L.M. Exergy Analysis of Hydrogen-Fueled Spark Ignition Engine Based on Numerical Investigations. In Combustion for Power Generation and Transportation; Agarwal, A., De, S., Pandey, A., Singh, A., Eds.; Springer: Singapore, 2017; pp. 297-316.

56. Castonguay, S. Green Technologies: Electric Cars with Hydrogen Fuel Cells. WIPO Magazine; World Intellectual Property Organization: Geneva, Switzerland, 2009; No. 2. Available online: https://www.wipo.int/wipo_magazine/en/2009/02/article_ 0009.html (accessed on 24 October 2020).

57. Veziroglu, T.N.; Sherif, S.A.; Barbir, F. Chapter 7-Hydrogen Energy Solutions. In Environmental Solutions; Agardy, F.J., Nemerow, N.L., Eds.; Academic Press: San Diego, CA, USA, 2005; pp. 143-180, ISBN 978-0-12-088441-4.

58. Schiro, F.; Stoppato, A.; Benato, A. Modelling and analyzing the impact of hydrogen enriched natural gas on domestic gas boilers in a decarbonization perspective. Carbon Resour. Convers. 2020, 3, 122-129. [CrossRef]

59. Norsk Hydrogenforum (the Norwegian Hydrogen Association). Sikkerhet. 2020. Available online: https://www.hydrogen.no/ ressurser / hva-er-hydrogen/sikkerhet (accessed on 3 January 2021).

60. College of the Desert. Hydrogen Fuel Cell Engines and Related Technologies; Rev 0, December 2001-Module 1: Hydrogen Properties. Available online: https:/ / www.energy.gov/sites/default/files/2014/03/f12/fcm01r0.pdf (accessed on 3 January 2021).

61. Li, D.; Zhang, Q.; Ma, Q.; Shen, S. Comparison of explosion characteristics between hydrogen/air and methane/air at the stoichiometric concentrations. Int. J. Hydrogen Energy 2015, 40, 8761-8768. [CrossRef]

62. Houf, W.; Winters, W. Simulation of high-pressure liquid hydrogen releases. Int. J. Hydrogen Energy 2013, 38, 8092-8099. [CrossRef]

63. Zhu, D.-Z. Example of Simulating Analysis on LNG Leakage and Dispersion. Procedia Eng. 2014, 71, 220-229. [CrossRef]

64. Hansen, O.R. Design optimization reflecting risk for a hydrogen storage and fuel cell system. In Proceedings of the Maritime Hydrogen and Fuel Cells Conference, Bergen, Norway, 3 September 2019.

65. Hansen, O.R. Liquid hydrogen releases show dense gas behavior. Int. J. Hydrogen Energy 2020, 45, 1343-1358. [CrossRef] 
66. Project Foreship. Engineering Considerations for Fuel Cell installation. In Proceedings of the Maritime Hydrogen \& Fuel Cells Conference, Bergen, Norway, 3 September 2019.

67. Lisowski, E.; Lisowski, F. Study on thermal insulation of liquefied natural gas cryogenic road tanker. Therm. Sci. 2019, 23, 1381-1391. [CrossRef]

68. Derwent, R.; Simmonds, P.; O’Doherty, S.; Manning, A.; Collins, W.; Stevenson, D. Global environmental impacts of the hydrogen economy. Int. J. Nucl. Hydrog. Prod. Appl. 2006, 1, 57. [CrossRef]

69. Xie, F.; Li, Y.; Zhu, K.; Ma, Y.; Wang, J. Cooling behaviors of liquid hydrogen by helium gas injection. Heat Mass Transf. 2019, 55, 2373-2390. [CrossRef]

70. SIGTTO. LNG Marine Loading Arms and Manifold Draining, Purging and Disconnection Procedure; SIGTTO: London, UK. Available online: https: / www.sigtto.org/media/2384/lng-marine-loading-arms-and-manifold-draining-purging-and-disconnectionprocedure.pdf (accessed on 31 May 2021).

71. IMO-International Maritime Organization. IGF Code_International Code of Safety for Ships Using Gases or Other Low-Flashpoint Fuels; IMO Publishing: London, UK, 2016. Available online: https://www.imo.org/en/OurWork/Safety/Pages/IGF-Code.aspx (accessed on 3 June 2021).

72. Aarskog, F.G.; Hansen, O.R.; Strømgren, T.; Ulleberg, Ø. Concept risk assessment of a hydrogen driven high speed passenger ferry. Int. J. Hydrogen Energy 2020, 45, 1359-1372. [CrossRef]

73. Schinas, O.; Butler, M. Feasibility and commercial considerations of LNG-fueled ships. Ocean Eng. 2016, 122, 84-96. [CrossRef]

74. European Commission. EU Commission Charts Path towards 100\% Renewable Hydrogen; Brussels, Belgium, 9 July 2020. Available online: https:/ / www.euractiv.com/section/energy/news/eu-commission-charts-path-towards-100-renewable-hydrogen/ (accessed on 20 July 2020). 